BANKING 


\title{
BANKING
}

\section{An introductory text}

\author{
PHILIP MOLYNEUX
}

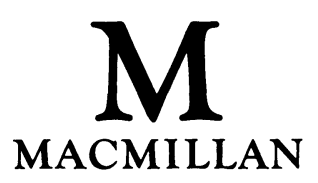


CC Philip Molyneux 1990

All rights reserved. No reproduction, copy or transmission of this publication may be made without written permission.

No paragraph of this publication may be reproduced, copied or transmitted save with written permission or in accordance with the provisions of the Copyright, Designs and Patents Act 1988 , or under the terms of any licence permitting limited copying issued by the Copyright Licensing Agency, 33-4 Alfred Place, London WC1E 7DP.

Any person who does any unauthorised act in relation to this publication may be liable to criminal prosecution and civil claims for damages.

First published 1991

Published by

MACMILLAN EDUCATION LTD

Houndmills, Basingstoke, Hampshire RG21 2XS

and London

Companies and representatives

throughout the world

Edited and typeset by

Povey/Edmondson

Okehampton and Rochdale, England

British Library Cataloguing in Publication Data

Molyneux, Philip

Banking: an introductory text.

1. Great Britain, Banking

I. Title

332.10941

ISBN 978-0-333-54120-3 ISBN 978-1-349-21153-1 (eBook)

DOI 10.1007/978-1-349-21153-1 


\section{CONTENTS}

$\begin{array}{ll}\text { List of figures } & \text { ix }\end{array}$

List of tables $\quad$ X

Preface xii

Acknowledgements xiii

1 General Description of the UK Financial System 1

Institutional Structure $\quad 1$

Deposit-taking Institutions $\quad 2$

Reporting banks $\quad 2$

Other deposit-taking institutions $\quad 7$

Other institutions and markets $\quad 8$

Non-bank financial intermediaries $\quad 8$

UK financial markets $\quad 9$

References and further reading $\quad 14$

2 Analysis of the Evolution of UK Markets and Financial Intermediaries $\quad 15$

Introduction $\quad 15$

Role of Financial Intermediation 15

Evolutionary Forces During the 1980s 17

$\begin{array}{ll}\text { Market environment and demand factors } & 17\end{array}$

$\begin{array}{ll}\text { Supply factors } & 23\end{array}$

References and further reading $\quad 30$

3 Claims, Financial Intermediation and the Development of Financial Systems

Introduction 31

Financial Claims and Financial Intermediation 31

Financial claims $\quad 31$

Financial intermediation $\quad 33$

The Development of the Financial System $\quad 36$

$\begin{array}{ll}\text { References and Further reading } & 40\end{array}$ 
4 The Classification of Financial Institutions 41

Introduction 41

Ways of classifying financial institutions $\quad 41$

What is a bank? $\quad 46$

Different types of UK financial institutions $\quad 47$

References and further reading $\quad 47$

5 The Concept of Money and how Banks Create Deposits 48

Introduction $\quad 48$

The concept of money $\quad 48$

What is money? 48

What function does money perform? 49

What are the necessary attributes of money? 50

How can we measure money? 51

Why do people/economic units hold money? 55

The credit multiplier or how banks create deposits $\quad 56$

The credit multiplier and leakages from the banking system $\quad 59$

How useful and how relevant is the concept of the credit multiplier? $\quad 61$

6 Major Services Provided by UK Deposit Banks 62

Introduction $\quad 62$

UK payment clearing systems $\quad 62$

The UK payments clearing system since December
1985

Non-cash methods of payment $\quad 65$

Cheque payments $\quad 65$

Giro payments $\quad 66$

Standing orders $\quad 66$

Direct debits $\quad 66$

Plastic cards $\quad 66$

Electronic funds transfer $\quad 68$

Deposit and lending facilities $\quad 70$

Deposits $\quad 70$

Lending facilities $\quad 72$

Branching and delivery systems $\quad 75$

$\begin{array}{ll}\text { Other services } & 77\end{array}$

$\begin{array}{ll}\text { References and further reading } & 78\end{array}$

7 Characteristics of UK Deposit Banks 79

Introduction $\quad 79$

The deposit or retail banks' balance sheet structure $\quad 79$

Clearing banks' balance sheet structures $\quad 81$

Branching and staffing $\quad 83$ 
Costs, income and profitability characteristics $\quad 85$

$\begin{array}{ll}\text { A note on market shares } & 89\end{array}$

Current issues facing UK banks $\quad 90$

References and further reading $\quad 92$

8 The Central Bank and Bank Regulation 93

Introduction $\quad 93$

Functions of a central bank $\quad 93$

The Bank of England $\quad 95$

Constitution of the Bank $\quad 96$

Functions and organisational structure of the Bank of England

Banking supervision, operations and corporate services $\quad 96$

$\begin{array}{ll}\text { Finance and industry } & 97\end{array}$

Policy and markets $\quad 97$

Banking role of the Bank of England 98

National debt management $\quad 98$

Production and distribution of bank notes $\quad 99$

Lender-of-last-resort $\quad 99$

Foreign exchange transactions $\quad 100$

Monetary policy 100

Banking regulation in the United Kingdom 102

$\begin{array}{ll}\text { Why regulate banks? } & 102\end{array}$

Scope of bank supervision $\quad 103$

Tools of supervision $\quad 104$

Domestic bank supervision 105

UK bank regulation - the international dimension $\quad 111$

The Basle proposals and EC legislation $\quad 112$

$\begin{array}{ll}\text { References and further reading } & 119\end{array}$

9 Recent Trends and Developments in Banking 120

$\begin{array}{ll}\text { Introduction } & 120\end{array}$

$\begin{array}{ll}\text { Forces generating change } & 120\end{array}$

Competition $\quad 120$

$\begin{array}{ll}\text { Regulation } & 122\end{array}$

Financial innovation $\quad 124$

$\begin{array}{ll}\text { Technology } & 127\end{array}$

Current trends and strategic issues facing banks $\quad 131$

Internationalisation $\quad 131$

$\begin{array}{lr}\text { Universalisation } & 132\end{array}$

Securitisation $\quad 132$

Globalisation $\quad 132$

Conglomeration 133

Concentration 134

$\begin{array}{ll}\text { References and further reading } & 135\end{array}$ 
10 Money Markets and International Banking 136

Introduction 136

London sterling money markets $\quad 136$

Characteristics of money market activities $\quad 136$

The London money markets $\quad 136$

$\begin{array}{ll}\text { The discount market } & 137\end{array}$

The parallel sterling money markets $\quad 139$

Treasury bill market $\quad 139$

Local authority market $\quad 139$

Sterling acceptance market 141

Sterling interbank market 141

Other markets $\quad 142$

The Eurocurrency markets $\quad 143$

Historical development 143

Nature of the eurocurrency markets 145

A note on the development of the eurobond market $\quad 146$

Regulation of the eurocurrency markets $\quad 147$

$\begin{array}{ll}\text { International banking } & 148\end{array}$

Foreign exchange markets $\quad 150$

Why is the market so large? 152

International financial centres 153

The international debt problem $\quad 154$

References and further reading $\quad 155$

11 European Financial Services and $1992 \quad 156$

Introduction $\quad 156$

EC Legislation and $1992 \quad 156$

Financial services in the EC - the impact of completing the internal market

Banking products and services $\quad 161$

References and further reading 166

12 Banking in the European Community and the Role of Large

Banks up to 1992

$\begin{array}{ll}\text { Introduction } & 167\end{array}$

Banking in the European Community 167

EC banking markets: an overview 167

$\begin{array}{ll}\text { The role of large banks } & 171\end{array}$

The structure and performance characteristics of the
largest banks in the EC

Ownership of the top banks in the EC 172

$\begin{array}{ll}\text { Conclusion } & 176\end{array}$

$\begin{array}{ll}\text { References and further reading } & 177\end{array}$

$\begin{array}{ll}\text { Glossary of terms } & 178\end{array}$

$\begin{array}{lr}\text { Index } & 188\end{array}$ 


\section{LIST OF FIGURES}

3.1 The link between borrowers and lenders 34

3.2 Financial intermediation 35

3.3 Primary and secondary securities 39

5.1 Relationships among the monetary and liquidity aggregates and their components prior to May 1987

5.2 Relationships among monetary aggregates and their components after May 1987 


\section{LIST OF TABLES}

1.1 Reporting banks' total assets and sterling deposits, December 1979 and December 1989

1.2 Total assets of the major non-bank financial intermediaries, December 1983-December 1989

1.3 Share ownership by investor type, 1963, 1984 and 1987

2.1 Net lending for house purchase by retail banks and building societies, 1978-87

2.2 Distribution of deposits: holdings of UK residents with principal institutions in the United Kingdom

2.3 Clearing banks and UK merchant banks after 'Big Bang'

2.4 Top 20 UK building societies: profile of services (excluding mortgages)

2.5 'Retail banking' and other consumer financial services of non-bank financial intermediaries

5.1 The case of a single bank under a 10 per cent cash ratio 56

5.2 The banking system under a 10 per cent cash ratio 58

6.1 Membership of APACS and the operational clearings, July 1987

6.2 Growth in payments, 1980-87 65

$\begin{array}{lll}6.3 & \text { Sources of consumer funds } & 71\end{array}$

6.4 Commercial lending share in Europe by 1995

6.5 Growth in the number of ATMs installed in Europe 75

7.1 Retail banks' balance sheet, 31 December $1987 \quad 80$

$\begin{array}{lll}7.2 & \text { Total assets of main UK banks } & 81\end{array}$

7.3 International assets as a percentage of total assets $\quad 82$

7.4 Balance sheet breakdown of individual UK banks, 1987 
7.5 Staffing levels and branch numbers of the UK clearing banks

7.6 Non-interest income as a percentage of total income 87

7.7 Profits of the UK deposit banks 88

7.8 Market shares: sterling deposits and sterling advances 90

8.1 The Basle proposals - definition of capital included in the capital base (to apply at end-1992)

9.1 Banking services based on electronic technology 130

9.2 Assets and deposits concentration measures 134

10.1 Important features of sterling money market instruments $\quad 140$

10.2 Average daily foreign exchange turnover by currency in 1986

11.1 Economic aspects of the European financial services sector

11.2 Estimate of potential falls in financial product prices as a result of completing the internal market

11.3 Estimated gains resulting from the indicative price reductions for financial sectors

11.4 Estimate of potential falls in individual financial product prices as a result of completing the internal market

11.5 Attractiveness of European markets

12.1 Market concentration and size of banking sectors in the EC, 1986

12.2 Structure and performance characteristics of the top banks in the EC for 1987

12.3 Statistical summary of the ownership of top banks in the EC, 1987

12.4 Potential big bank acquisition targets in the EC up to 1992 


\section{PREFACE}

Banking markets have witnessed considerable change over the last decade and the pace of change will no doubt continue given 1992 and the inevitability of a single European banking market. The aim of the text is to provide a detailed coverage of the UK banking and financial system together with an overview of various theoretical issues relating to banking. In addition this text analyses the main trends and developments affecting UK and European banks. The first half of the book concentrates on the UK financial system and various theoretical issues whereas the second part places greater emphasis on various international aspects, especially the implications of 1992. In particular, Chapter 8 examines the main regulatory issues facing UK and European banks, Chapter 9 covers recent trends and developments in banking, Chapter 10 looks at money markets and international banking and the final chapter examines in detail the main characteristics of European Community banking markets.

The bulk of this book is based on my first-year undergraduate lecture notes for banking and finance students at the University College of North Wales, Bangor. Many thanks to Helen Treece for doing an effective job on a difficult manuscript and to the staff of the Institute of European Finance for the time and resources they afforded on work relating to this text. Finally, I wish to thank Delyth, Lois and Rhiannon, without whose encouragement and understanding this text would never have been completed.

PHILIP MOLYNEUX 


\section{ACKNOWLEDGEMENTS}

The author and publishers are grateful to the University of London External Advisory Service for copyright permission to reproduce some of the author's lecture notes that have appeared in a different form in their BSc (Economics) Degree Banking One Study Guide; and to the editors of Regional Studies for use of part of an article that appeared in the December 1989 issue (used in the final chapter of this text). 